\title{
A SURVEY OF THE YOUTH AGED 16-19 IN KLAIPEDA MUNICIPALITY: LIVING CONDITIONS AND THE FUTURE
}

\author{
GIEDRE் STRAKSIENE $\dot{1}^{1}$
}

Klaipèda University (Lithuania)

\begin{abstract}
The purpose of this paper is to provide an initial description of youth policy and highlight some relevant data. There has been conducted a survey in the framework of CaSYPoT project (Capacity Building for Strategic Youth Policy and Transnational Cooperation) under the Interreg South Baltic Programme 2014-2020 (Project No. STHB.05.01.00-SE-0024/15). The overall aim of this project is to encourage young people to get involved into local democracy and to present the youth as the resource in the development of society and democracy. The goal of the project is the survey that was carried out in Klaipeda municipality, in the period of April-May 2017. Thus, the article analyses the findings of this survey. The questionnaire contained questions addressing young people's wellbeing and safety in their neighbourhood and at school, as well as their experience getting involved in the municipality work and their influence on its decisions. The target group of the survey was young people aged 16-19.

KEYWORDS: young people, students, youth policy and strategy, Klaipeda municipality, SBP project "CaSYPoT".
\end{abstract}

JEL CODES: H51, H52, H53, H75.

DOI:

\section{Introduction}

With hope that this increases the dialogue between young people and the decision-makers (local politicians).

Youth policy, according to the approach of the Council of Europe youth sector, combines a multi-dimensional concern ensuring young people's well-being, providing them with relevant learning opportunities, increasing the probability of their successful integration into society and transition to autonomy, thus enabling them to participate in decision-making and the civil society. This multi-faceted focus on different aspects of young peoples' lives is supported by a set of principles on which sound policy-making should be based (The Future of the Council of Europe Youth Policy: AGENDA 2020", 2008: 5).

As stated in the document "Youth Policy in Lithuania" (2010), one of the key elements for a successful youth policy is a continuous cooperation between the State Council for Youth Affairs and other Government departments and Municipalities which are involved in a specific areas of youth affairs or matters. Furthermore, "The National Youth Policy Development Program for 2011-2019" (Dèl nacionalinès jaunimo politikos 2011-2019 metu pletros patvirtinimo, 2010) has one of the following purposes to ensure the cooperation among the departments and sectors in developing a cohesive youth policy based on evidence and knowledge (Lithuanian Youth Policy: Legislation, Structures, Good Practices, 2013: 8).

Analysing the youth situation in Lithuania during the past decade, scientists and local actors indicate various causes of the current situation: lack of information on important issues as well as motivation of youth to express interest in future perspectives, lack of interesting leisure activities in municipalities, decreasing interest in studies, requiring higher intellectual endeavours, etc. (Galimybių studija "Klaipedos jaunimo situacijos tyrimas", 2015; Jaunimo situacijos Kauno mieste tyrimas, 2011; Liukineviciene, 2011; Abariute, Kazlauskiene, 2009, and others). It

\footnotetext{
Giedrė Strakšienè - PhD at Klaipeda University, Faculty of Social Sciences, Centre of Social Changes

Scientific interests: science communication, science and art communication, development of communication

E-mail: giedre.straksiene@ku.lt
} 
was noted the lack of research on indicating changes in the future expectations of young people depending on their age, school profile, home environment conditions, health situation, reasons for selecting priorities, etc. Institutions of higher education in Lithuania have possibilities to carry out researches on the effect of youth policy implemented during the recent years as well as can prognosticate relevant tendencies in the future.

It must be noted that due to demographic and economic changes Klaipeda has fallen into a period of non-progression. The geographical distance from the major cultural centres (Vilnius, Kaunas) is further adding to the region's provinciality. Moreover, most of young people want to move away from municipality, they do not want to stay in the region. How should the municipality react? What relevant actions should be appropriate for municipalities having that in mind? The research problem suggested the following questions: How are young people doing? Are young people satisfied with their living and studying conditions in their municipality? What problems do they identify? Let us suppose, that we have to make changes now, because it will enable to keep our young people, attracting professionals of various fields, activating the community, and thus ensuring the desire of the city to move forward.

In autumn 2016, the project "Capacity Building for Strategic Youth Policy and Transnational Cooperation" (CaSYPoT) was launched and implemented by Klaipeda University (Centre of Social Changes) under the Interreg South Baltic Programme 2014-2020 (Project No. STHB.05.01.00-SE-0024/15). CaSYPoT project focuses on the cooperation of the different Euroregion Baltic actors: local and regional authorities, universities, NGOs, etc., in the field of youth questions. The main goal of the project is to improve the cross-border capacity of these local actors through cooperation in the youth field, mainly by carrying out a survey among youngsters and based on its results to create a knowledge-based strategic youth policy. Through cross-border cooperation the project partners were expected to develop joint solutions for young people so that to improve their lives in the local communities. This way, the local actors were expected not only to work on youth issues, but also to gain new knowledge and experience, in cross-border cooperation in the South Baltic (SB) region.

In the context of the project, the survey aimed to investigate young people's life conditions in six municipalities located in the South Baltic region. The project partners are: Sweden (Municipality of Emmmaboda; Regional Council in Calmar County; Linnaeus University); Poland (Association of Polish Communes Euroregion Baltic; City of Slupsk, University of Gdansk); Russia (Agency for Youth Affairs of the Kaliningrad region; Municipalities of Svetlogorsk and Gusev; Immanuel Kant Baltic Federal University), and Lithuania (Klaipeda University). The partner municipalities carried out a survey about teenagers (aged 16-19) identifying their needs and problems and providing comparable data. It is a form of sharing good practice, as the survey had been formerly developed and implemented in Sweden. Later it was adjusted to the national context of other countries. The obtained results have been analysed by universities and compared between the countries. Based on them, a joint knowledge-based youth strategy will be created in ERB as well as in the participating municipalities. It will allow to address several youth problems in the South Baltic area. Additionally, more tools for maintaining a dialogue with the youth and increasing their participation will be developed and tested in the nearest future.

The aim of this article is to analyse the results of the survey concerning the young people experience, opinions and views of their present and future life situation as well as the society where they live, i.e., Klaipeda municipality. The ambition is to present results and conclusions that can be of use when identifying various needs, designing appropriate action plans and concrete interventions in relation to youth policies in the municipality.

Research methods: literature review, survey research (questionnaire as an instrument) and basic data analysis, descriptive statistics.

The survey was inspired by the Swedish LUPP survey, yet it has been modified to enable comparisons with a number of municipalities in the South Baltic region. Working with researchers from Linnaeus University and the project partners across the South Baltic, we created an on-line survey instrument to assess the youth situation in Klaipeda municipality. The questionnaire consisted of several sections, which covered such topics as: free time, school, health, family; attitude to issues of social development and security; plans for the future or migration plans. We were particularly interested in examining effective and ineffective strategies looking at them from a students' perspective.

Organization of the survey. The survey completed students aged 16-19 and representing nine schools in Klaipeda municipality. At the beginning, in the confidential online questionnaire young people are asked to indicate 
demographic information about them and their parents (guardians), then proceed questions addressing the young people's experience about well-being and safety in their neighbourhood and at school, as well as their experience to be involved in the municipality's work so that to have influence on decision-making in the municipality they live.

The total number of respondents amounts to 473 . In total, 404 surveys have been collected. This provided with an answering frequency of $85 \%$, which is regarded as high. However, we also observed internal data loss. The majority of questions in the survey were answered by 404 young people (of which $214(53 \%)$ were males and 190 (47\%) - females), however, occasional questions have a very low answering frequency, less than $50 \%$. Consequently, the information must be interpreted with caution.

Students who participated in the survey were from gymnasiums/upper secondary schools (75\%), vocational education (22\%), and other profile (3\%) in the Klaipeda municipality. Seeking to encourage participation in this research, schools were assured of anonymity and confidentiality.

\section{Summary of the Results}

\subsection{Family environment of young people}

The socio-demographics information about the respondents shows that the majority of them (91\%) were born in Lithuania, the same as their parents (mothers $-90 \%$; fathers $-86 \%$ ). Just a very small part of them stated that they were born in the Baltics States (Latvia, Estonia), in Europe or outside Europe. The students who were not born in Lithuania stated that they had lived in Klaipeda for 10 years and more (49\%), 4-9 years $(22 \%)$ and $0-3$ years $(30 \%)$. Also, $74 \%$ of the respondents wrote that their mother works in Lithuania and $62 \%$ responded that their father works in this country as well. However, $18 \%$ responded that their father works abroad. Data about the parent's education shows that the respondents' mothers completed the upper secondary education (22\%), while the number of educated fathers amounted to $31 \%$. There were observed $35 \%$ of fathers and $49 \%$ of mothers who had the university education (tertiary level), which means that there is a high number of parents who have the secondary and university education.

The respondents were more or less concerned about the financial situation of their parents. When young people were asked about their parents' finances, the results showed that most of the respondents were rather worried (42\%) or very worried (26\%) about their parents' financial situation. It was no surprise, because the students' answers reflect the low economic level in Lithuania. There were some students, who admitted that their parents could not always painlessly cover additional expenses of their children.

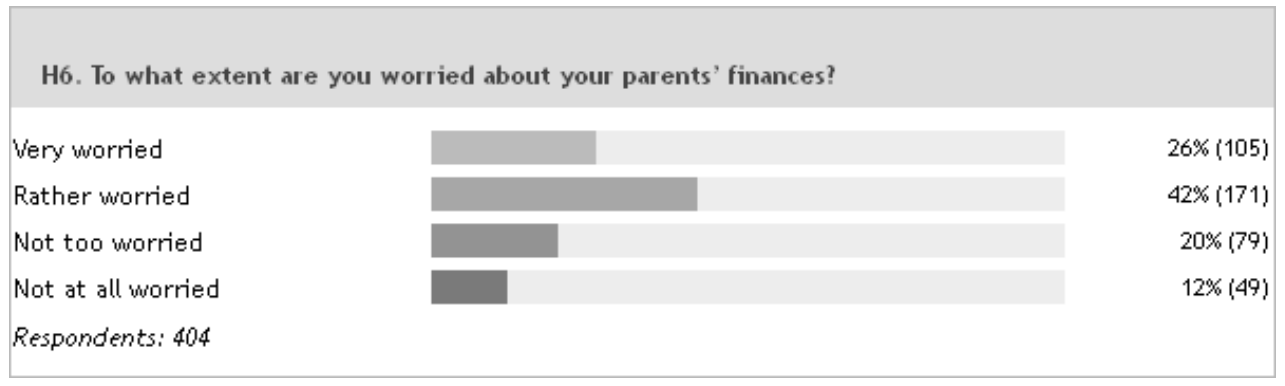

Fig. 1. Financial worries (percentages)

Source: CaSYPoT project website: http://casypot.eu/project/

\subsection{Free time (leisure) activities of young people}

In the first part of the questionnaire about the lifestyle of the youth, we were mapping the activities outside the school. (It was found out that $11 \%$ of the respondents had some illness or disability, which means that they have difficulty participating in various activities during their leisure time). 
More than half number of the respondents partly agree (this means statements are 'partly true') with these statements: "There are things to do but nothing interesting to me" (54\%); "There are things to do but I cannot get there" (50\%); "There are things to do, but it costs too much" (47\%). A larger proportion of girls stated that they were not able to go and do something with their friends because they could not afford it. In Klaipeda municipality, $76 \%$ of the respondents said that their parents allow them to participate in various leisure activities.

To find out about the main activities in their spare time, students were asked to determine how often they were engaged in certain areas. The questionnaire offered 16 categories and an open answer, where additional information or explanations could be given. The respondents could choose several answers. The biggest percentage $(77 \%)$ of the respondents stated that they prefer to use social media (Figure 2) several times per week; $58 \%$ of the respondents stated that they engage in sport activity several times per week and $41 \%$ of them claimed that they play video/computer/online games several times per week. Just 7\% never use social media, 9\% is not interested in sport at all and $19 \%$ never play video or online games. It is worth noting that the youth is spending time browsing the Internet or chatting online with friends. It is a natural result of the century focusing on innovative technologies.

\begin{tabular}{|lr|}
\hline Use social media & \\
\hline Never & $7 \%(32)$ \\
About once per year & $3 \%(15)$ \\
About once per month & $4 \%(17)$ \\
Once per week & $9 \%(43)$ \\
Several times per week & $77 \%(366)$ \\
Respondents: 473 & \\
\hline
\end{tabular}

\begin{tabular}{|lr|}
\hline \multicolumn{1}{|c|}{ Exercise/do sports } \\
\hline Never & $9 \%(44)$ \\
\hline About once per year & $5 \%(23)$ \\
About once per month & $8 \%(40)$ \\
Once per week & $20 \%(93)$ \\
Several times per week & $58 \%(273)$ \\
Respondents: 473 & \\
\hline
\end{tabular}

\begin{tabular}{lr|}
\hline Play video games, online games or computer games \\
\hline Never & $19 \%(89)$ \\
About once per year & $10 \%(46)$ \\
About once per month & $16 \%(77)$ \\
Once per week & $14 \%(66)$ \\
Several times per week & $41 \%(195)$ \\
Respondents: 473 & \\
\hline
\end{tabular}

Fig. 2. The most popular activities (percentages)

Source: CaSYPoT project website: http://casypot.eu/project/

Apart from those mentioned above, which were the most common answers, it is also important to note that young people in Klaipeda municipality like to spend free time in nature. Summing up, $68 \%$ of the respondents go out to nature once or several times per week. 


\begin{tabular}{|lr|}
\hline Go out into nature & \\
\hline Never & $5 \%(24)$ \\
About once per year & $4 \%(20)$ \\
About once per month & $23 \%(108)$ \\
Once per week & $32 \%(149)$ \\
Several times per week & $36 \%(172)$ \\
Respondents: 473 & \\
\hline
\end{tabular}

Fig. 3. Spare time in nature (percentages)

Source: CaSYPoT project website: http://casypot.eu/project/

The students of Klaipeda municipality are not interested in activities organized by church, politicians or social activities. The majority of respondents answered that they never visit religious organizations. However, a significant number of the interviewed go to church or take part in religious activities at least once a year. Perhaps, they visit religious institutions together with their family on major religious holidays. Yet, young people never go to a youth (or youth leisure) centre (57\%), a bit less percentage of the respondents $(43 \%)$ never go to church or religious events and also $42 \%$ of them do not prefer to act, play music or dance.

\begin{tabular}{|lr|}
\hline Go to a youth centre, leisure centre or similar \\
\hline Never & $57 \%(268)$ \\
About once per year & $15 \%(71)$ \\
About once per month & $13 \%(61)$ \\
Once per week & $9 \%(42)$ \\
Several times per week & $7 \%(31)$ \\
Respondents: 473 & \\
\hline
\end{tabular}

Go to church or to religious events

Never

About once per year

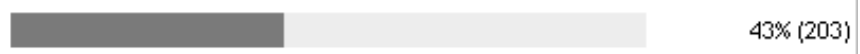

About once per month

$32 \%$ (151)

Once per week

$13 \%(62)$

Several times per week

$8 \%(40)$

Respondents: 473

$4 \%(17)$

Act, play music or dance

Never

About once per year

About once per month

Fig. 4. Unpopular activities in spare time (percentages)

Source: CaSYPoT project website: http://casypot.eu/project/ 
The survey results show that approximately once per month the respondents visit library (35\%), go to a party (34\%), go to see games or other sporting events (28\%). It turned out that in their leisure time students are less engaged in visiting concerts, theatres, museums or exhibitions. Most of the respondents noted that they attend such events once a year. Here they are most likely to visit such events with their classmates under the guidance of a teacher. A very small percentage of students visit such events weekly or more often. The activities that young people do at least once per year: go to museums or exhibitions (49\%); go to concerts (43\%); go to theatres, musicals or dance performances (34\%).

It is necessary to note that in Klaipeda there are just a few museums, musical and drama theatres. It is supposed that the question of low attendance of concerts or drama performances is connected with the price of tickets. It was no surprise that more than half of the respondents (54\%) stated that they spend most of their leisure time with friends at each other's home, in the city downtown (52\%), and at a coffee shop (42\%).

Summing up, young people (almost half of them (47\%)) think that they have not enough recreational activities in Klaipèda municipality.

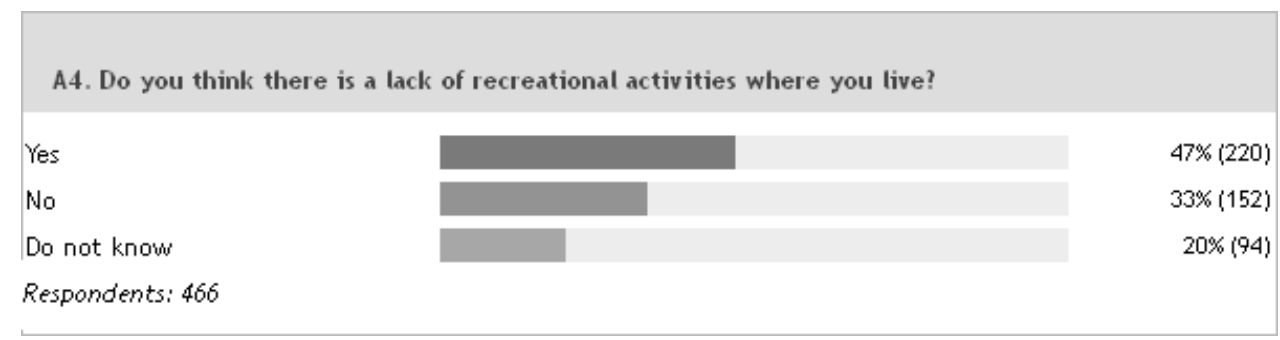

Fig. 5. Assessment of the recreational activity (percentages)

Source: CaSYPoT project website: http://casypot.eu/project/

The surveyed young people are not interested in society (association) activities, and to the question whether they are members of any associations $72 \%$ of respondents answered negatively.

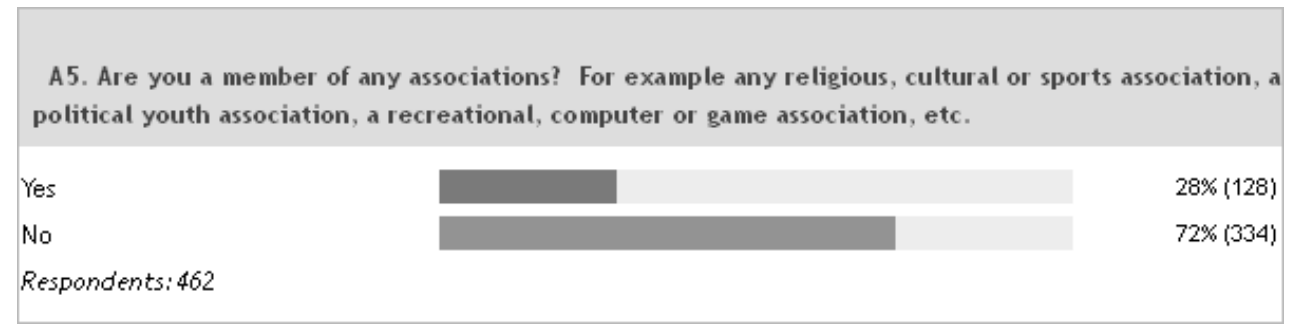

Fig. 6. Membership in various associations (percentages)

Source: CaSYPoT project website: http://casypot.eu/project/

\subsection{School, education, environment and atmosphere at schools}

Firstly, it should be noted that $97 \%$ of young people from our survey sample attend a school (gymnasium or vocational school).

Analysing the atmosphere at school, most of the young people indicate the atmosphere at school as positive $(65 \%)$ ('largely true' (33\%) and 'completely true' (32\%)). Only $11 \%$ of them have the rigorously opposite opinion. This shows the appreciation of work done by the school administration and teaching staffs. Other answers to the questions related with atmosphere at schools are quite positive:

- Sexual harassment is seen as an issue only by $13 \%$ ('largely true' (6\%); 'completely true' (7\%)) of the respondents. Yet, $50 \%$ do not identify this issue at their school.

- Both genders of young people equally feel about their equal opportunities at school: 'largely true' (24\%); 'completely true' (36\%). 
- Also, $44 \%$ of respondents ('largely true' (24\%); 'completely true' (20\%)) state that the school solves problems related with teachers' aggressiveness towards their students, however, $18 \%$ of them think otherwise ('not true at all').

- Moreover, $65 \%$ of respondents think there exists a mutual respect between students and teachers ('largely true' (37\%); 'completely true' (28\%)), and only $13 \%$ of respondents 'strongly disagree'. This clearly shows a positive trend in the perception of student-teacher relationship by the young people.

When it comes to bullying occurrence at school, $13 \%$ of respondents do not notice any bullying cases at schools, yet $24 \%$ admit that it is a serious problem ('completely true'), and $20 \%$ say that it is 'largely true' (Figure 7). Bullying seems to be a bigger problem among young people in Klaipeda municipality. Despite the above mentioned, when the bullying occurs at school, 59\% ('largely true' (24\%); 'completely true' (35\%)) of the respondents claim that the school acts/reacts to it.

\begin{tabular}{|lr|}
\hline Bullying occurs in my school & \\
\hline Not true at all & $13 \%(58)$ \\
Somewhat true & $30 \%(134)$ \\
Largely true & $20 \%(91)$ \\
Completely true & $24 \%(108)$ \\
Do not know & $13 \%(59)$ \\
Respondents: 450 & \\
\hline
\end{tabular}

Fig. 7. Bullying at school (percentages)

Source: CaSYPoT project website: http://casypot.eu/project/

The next part of questions focuses on the internal democracy at schools. There was an aim to find out the level of participation of the youth and their opportunities to influence the decision making at schools.

Approximately one third (28\%) of the respondents claim that they have been informed about students' councils (or students' influence), but only small part (22\%) of the respondents think that the school takes the council or student parliament seriously.

\begin{tabular}{|c|c|}
\hline \multicolumn{2}{|c|}{ I've been informed about what students should be able to influence in school } \\
\hline Not true at all & $16 \%(72)$ \\
\hline Somewhat true & $15 \%(67)$ \\
\hline Largely true & $17 \%(75)$ \\
\hline Completely true & $28 \%(127)$ \\
\hline Do not know & $24 \%(109)$ \\
\hline \multicolumn{2}{|l|}{ Respondents: 450} \\
\hline \multicolumn{2}{|c|}{ The school staff listen to what the student council says and takes them seriously } \\
\hline Not true at all & $11 \%(51)$ \\
\hline Somewhat true & $13 \%(60)$ \\
\hline Largely true & $27 \%(120)$ \\
\hline Completely true & $22 \%(97)$ \\
\hline Do not know & $27 \%(122)$ \\
\hline Respondents: 450 & \\
\hline
\end{tabular}

Fig. 8. Students' influence at school (percentages)

Source: CaSYPoT project website: http://casypot.eu/project/ 
Other questions presented the following results:

- Big part of the respondents (70\%) would like to have more influence on the learning curriculum, and only $14 \%$ are not interested in it at all.

- Yet $65 \%$ of the respondents would like to have influence on the exams, and only $17 \%$ are not interested in it at all.

- The respondents would like to have influence on the schedule $(61 \%)$, and only $15 \%$ are not interested in it at all.

- Nearly half of the students would like to have influence on such things as homework (uncountable), learning process and style.

\subsection{Politics, society and young people}

The results of the survey show that young people in Klaipeda municipality are not interested in politics, as only $33 \%$ answered positively ('very interested' (11\%); 'rather interested' (22\%)).

\begin{tabular}{|l|r|}
\hline Politics & \\
\hline Not at all interested & $35 \%(151)$ \\
Not too interested & $32 \%(136)$ \\
Rather interested & $22 \%(94)$ \\
Very interested & $11 \%(45)$ \\
Respondents: 426 & \\
\hline
\end{tabular}

Fig. 9. Students' interest in politics (percentages)

Source: CaSYPoT project website: http://casypot.eu/project/

As the findings show, young people perceive politics and social matters differently. The answers suggest that the biggest number of students (38\%) state that they are rather interested and $13 \%$ indicate that they are very interested in social matters.

\begin{tabular}{l|r|}
\hline Social matters in general & \\
\hline Not at all interested & $21 \%(90)$ \\
Not too interested & $28 \%(118)$ \\
Rather interested & $38 \%(162)$ \\
Very interested & $13 \%(56)$ \\
Respondents: 426 & \\
\hline
\end{tabular}

Fig. 10. Students' interest in social matters (percentages)

Source: CaSYPoT project website: http://casypot.eu/project/

The most negative answers $(67 \% ; 66 \% ; 62 \%)$ occurred in the question on social and political activities. Students were asked if they had done any of the following activities over the last 12 months (Figure 11). 


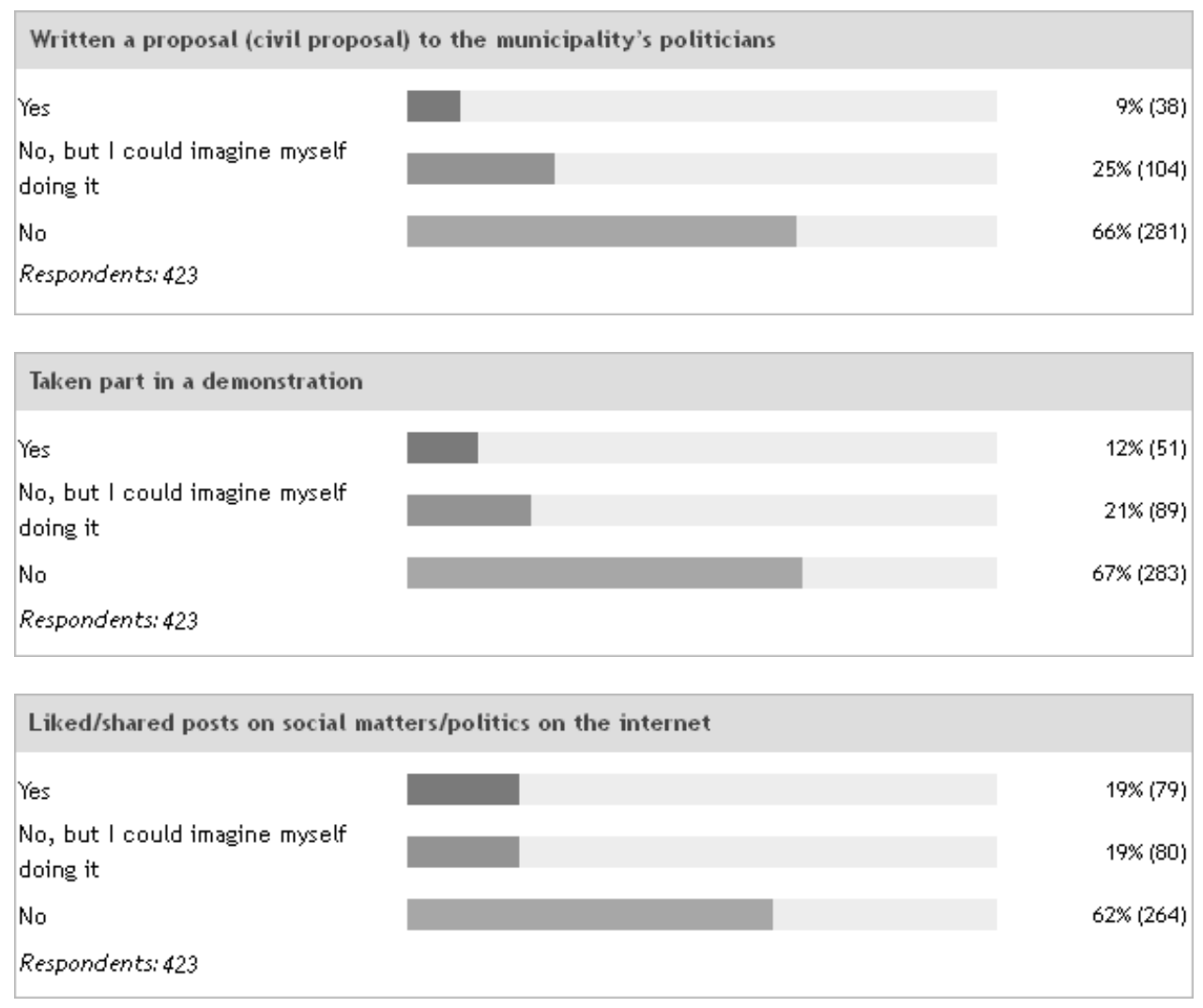

Fig. 11. Students' social and political activities during the past 12 months (percentages)

Source: CaSYPoT project website: http://casypot.eu/project/

Answers to the question related with decision making in their municipality were more or less equally balanced: 'yes' (53\%); 'no' (47\%).

Yong people were also asked to whom and where they go if they want to influence something in their municipality. According to their answers, the respondents would like 'to make contact with someone they know' (58\%), "an organised youth group that has the ability to influence' (45\%), and 'internet/social media' (38\%).

The responses of the young people in Klaipeda municipality show that they trust most their parents (69\%); rather a lot trust their teachers (42\%) and police (41\%). Inversely, the students very little trust politicians $(60 \%)$, priests or other religious leaders $(39 \%)$, and adult neighbours $(29 \%)$ as well.

\subsection{Safety of young people}

In general, the findings in the area of safety of the youth confirm that Lithuania is a safe country. The high level of safety was found in the domestic environment. When it comes to how often they feel safe in different places, the answers distributed two ways:

1) A large part of students (73\%) claim that they feel safe at home.

2) In other places, such as at school, in the city centre, bus, or the way to or from school, the respondents claim that "most of the time" they feel safe, so the answers vary from $22 \%$ to $47 \%$.

A large part of the respondents in Klaipeda municipality indicated that during the past six months they had not been exposed to sexual violence/abuse (84\%); had not been rifled (77\%); or threatened (69\%). The other examples of bulling, harassing or excluding comes to the similar result ( $71 \%$ the negative answers), and the other options were more or less equally balanced $(10 \% ; 9 \% ; 10 \%)$. As the most unsafe places, the respondents indicated: (1) school (42\%); (2) the internet/mobile phone (23\%), and (3) the way to/from school $(23 \%)$. 


\begin{tabular}{|c|c|}
\hline $\begin{array}{l}\text { D3b. Where were you bullied, harassed or excluded? } \\
\text { answer. }\end{array}$ & In this question you can choose more than one \\
\hline At home & $20 \%(25)$ \\
\hline In someone else's home & $8 \%(10)$ \\
\hline In my residential area & $11 \%(14)$ \\
\hline On the way to or from school & $23 \%(28)$ \\
\hline In school & $42 \%(51)$ \\
\hline $\begin{array}{l}\text { During a workout or organised } \\
\text { recreational activity }\end{array}$ & $11 \%(14)$ \\
\hline $\begin{array}{l}\text { At the youth centre, leisure } \\
\text { centre or similar }\end{array}$ & $8 \%(10)$ \\
\hline At church & $15 \%(18)$ \\
\hline In the city or city centre & $18 \%(22)$ \\
\hline On the bus, train or similar & $11 \%(13)$ \\
\hline $\begin{array}{l}\text { On the internet/my mobile } \\
\text { phone }\end{array}$ & $23 \%(28)$ \\
\hline Other & $10 \%(12)$ \\
\hline Respondents: 122 & \\
\hline
\end{tabular}

Fig. 12. The unsafe places identified by respondents (percentages)

Source: CaSYPoT project website: http://casypot.eu/project/

The good news is that $70 \%$ of the respondents claim that they know where they could turn for the support.

\subsection{Health}

When young people were asked whether they felt healthy (over the last 6 months), 57\% of them replied positively. Almost one-third (28\%) of the all respondents chose the answer "neither good nor poor". On the other hand, more than $10 \%$ of the youth often (several or once time per week) struggles with headaches, stomach-aches and problems with sleep. Also, one third of the young people feel stressed, irritated (28\%) and nervous (29\%).

An optimistic (but possible it is not realistic, as in the streets, café and restaurants we still see more young people who smoke) answer came up into the question about smoking where $64 \%$ of the respondents claim they do not smoke. On the other hand, $15 \%$ are regular smokers and $6 \%$ are e-cigarettes smokers.

When it comes to alcoholic drinks, the situation is similar. Never or seldom drink beer or cider (57\%); wine (63\%); spirit drinks (67\%). The other frequencies: drink alcohol once per week from $3 \%$ to $5 \%$, daily $-4 \%$ to $5 \%$ of the respondents. The respondents wrote that they usually buy alcohol themselves. As alarming thing is the finding that $11 \%$ of the respondents felt drunk once per week, and $13 \%$ - several times per week. The situation could be prevented by stricter approach of parents, as only $44 \%$ of them clearly forbid drinking alcohol.

In addition, $71 \%$ of the respondents never tried drugs. At the same time, however, $7 \%$ of them 'used often', and sometimes $(10 \%)$. The most popular types of drugs indicated and used are hash, marijuana, ecstasy and cannabis.

\subsection{Work and summer jobs}

Economic situation in Lithuania requires young people to get a part-time job or summer job. Apart from improving the family financial situation, most parents consider part-time or summer jobs an ideal opportunity for the youth to change their attitude to money.

Therefore, currently $16 \%$ of the respondents have a job. According to the respondents, they work approximately 16 hours per week (from 2 or 4 hours to 20 or 40 hours). When asked why they do not have a job, 
the most popular answers were "I do not have time for a job" (40\%) and "I haven't been able to find a job/ no interesting job offers" (28\%).

When asked whether they can imagine themselves starting their own business, the answers of young people showed a positive trend, as $66 \%$ wrote that they can imagine it.

\subsection{Future visions}

The last part of the survey focuses on the youth ideas about their future. In most cases, the answers sound optimistic and ambitious.

The most common answer to the question about future plans after graduating the upper secondary school/ gymnasium/vocational school was the respondents' wish to like/enjoy studying at the university or college in Lithuania $-35 \%$ of the answers. Also, $23 \%$ of students, which is quite a high number, wrote that they would like to study abroad. Yet $10 \%$ of the respondents claimed that they would like to work in Klaipeda municipality or nearby it. The other answers are in minority. Looking at the open question, several respondents wrote they would like to make their living as sportsmen or establish their own business.

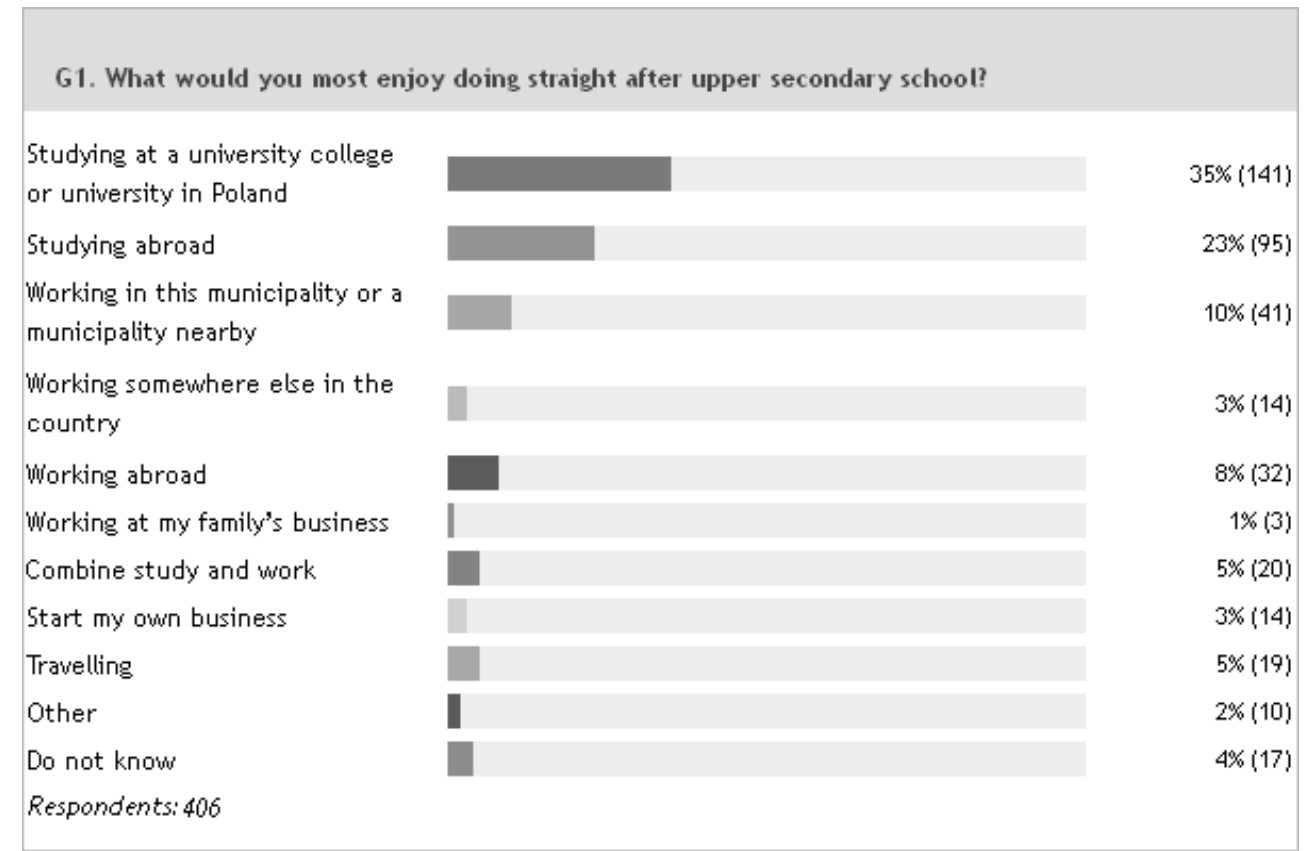

Fig. 13. Future plans after finishing school (percentages)

Source: CaSYPoT project website: http://casypot.eu/project/

Despite being a relatively dynamic town and region with more opportunities in the west of Lithuania, only $29 \%$ of the respondents do not have plans to move out of Klaipeda.

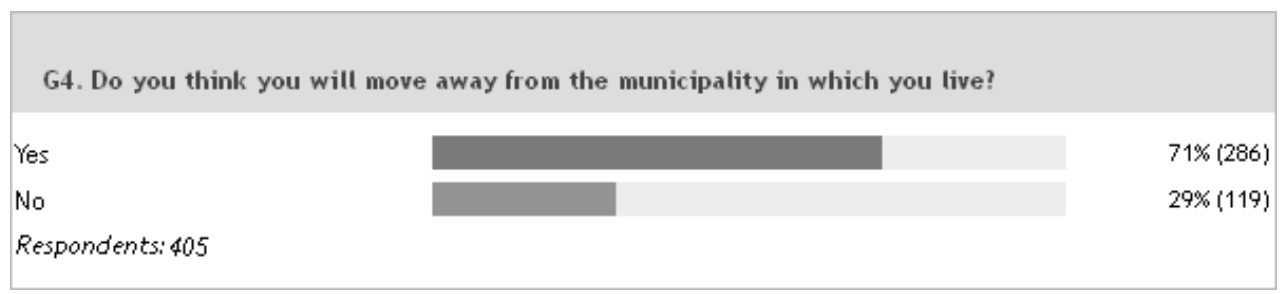

Fig. 14. Leaving the municipality (percentages)

Source: CaSYPoT project website: http://casypot.eu/project/ 
As it is seen from the data, $71 \%$ of the respondents think they will leave the town. The main (very important) reasons for this are:

- $38 \%$ - study opportunities;

- 36\% - job opportunities;

- $33 \%$ - family and relatives;

- $30 \%$ - better environment for children to grow up;

- $28 \%$ - housing situation in the municipality;

- $27 \%$ - friends or girl/boyfriend/partner.

Among the answers to the open question there were listed some reasons for leaving the town. The respondents mainly indicated disappointment with politics in Lithuania and in Klaipeda, unfair and wrong systems of finances and social matters, expensive basic goods. For example, "in my city, there are no opportunities for development, there is no opportunity to work properly", "few opportunities", "there is little work and few people here", "there are few prospects", "a small town", "there isn't enough space", "it's hard to find a good, well-paid job", "awful living conditions", "I don't want to live here", "it doesn't matter", "here's the bottom", "no idea", "not enough people", "I don't want to live here all my life", "I'd like to get good education abroad", "I want to leave not only my city, but also the country", "I'll go abroad", etc.

\section{Final remarks}

Summing up, this survey reflected the opinion of young people on many aspects of modern life and revealed a high degree of interest in solving a range of problems.

The safest place for the interviewed students is home or territory located near the place of living. A significant number of students admitted that they faced such problems as bullying, and the largest number answered that it was happening at school, and on the Internet. Most of the children answered that they know where to go for help in case of danger. The survey showed that parents and adults have a high degree of confidence in adolescents, whereas politicians and religious figures - the least confidence. Most of the students seek to achieve something in life, spend a lot of time studying, practice interesting hobbies. Most of them are interested in social issues, as well as local problems or events occurring in the world. Most of the respondents think about migration from their locality in the future. Studies abroad, well paid job and family ties appeared to be some of the most important reasons that influence the students' decision to move away from their municipality. Many teenagers have not yet decided on their future profession, while some of them want to continue their education in order to have a well-paid job in the future.

Sometimes, there were observed utterly rude and disrespectful answers, which revealed the level of the person's upbringing. Spelling, stylistic and grammatical errors were quite frequent. Nevertheless, it can be noted that in the overwhelming majority of cases, the students responded with interest, frankly and emotionally, which was especially evident in the answers to open-ended questions.

\section{Acknowledgement}

The contents of this study are the sole responsibility of the author[s] and can in no way be taken to reflect the views of the European Union, the Managing Authority or the Joint Secretariat of the Interreg South Baltic Programme 2014-2020.

\section{References}

Abariūtė, J., Kazlauskienė, A. (2009). Jaunimo situacijos tyrimas Šiaulių mieste (aktyvaus dalyvavimo jaunimo organizacijose kontekstas). Jaunuju mokslininku darbai, Nr. 2 (23). Available at: http://etalpykla.lituanistikadb.lt/fedora/ get/LT-LDB-0001:J.04 2009 1367166919569/DS.002.0.01.ARTIC

Biliūtè-Aleknavičienè, E. (2004). Jaunimo organizacijos poreikis asmenybès savirealizacijai. Pedagogika, T. 73, p. 141-149. 
Dèl nacionalinés jaunimo politikos 2011-2019 metu plètros patvirtinimo. (2010). 2010 m. gruodžio 1 d. Nr. 1715 . Available at: https://e-seimas.lrs.lt/portal/legalAct/lt/TAD/TAIS.387971.

Dumbliauskienè, M., Jarmalavičienè, S. (2012). Gyvenimo kokybės kompleksinio vertinimo metodologinès problemos. Geografijos metraštis, Nr. 45, p. 3-16.

Ethical Standards in Research. (2007). Available at: https://www.srcd.org/about-us/ethical-standards-research

Galimybiu studija „,Klaipédos jaunimo situacijos tyrimas “. (2015). Socialinių mokslų kolegija, Klaipėda.

Hansén, C., Skålmedal, J. (2015). 16-19 Years Old Youth Questionnaire Lupp. Ungas livssituation i siffror. Lupp 2015 - Emmaboda kommun. Fakulteten för samhällsvetenskap Utrednings- och forskningsservice Linnéuniversitetet). Available at: https://drive.google.com/a/dest.smk.lt/file/d/0B9KN_y33MqruVWRKZ0ZZdmVMSmc/view; http:// www.youthpolicy.org/national/Lithuania_2003_Youth_Policy_Review.pdf

Ilgalaike jaunimo problematikos tyrimu koncepcija. (2010). Available at: http://www.jrd.lt/uploads/ES\%20I/Ilgalaike_ jaunimo_prob.\%20koncepcija.pdf.

Jaunimo politikos igyvendinimo savivaldybėse kokybės vertinimas. (2012). Klaipédos miesto savivaldybès vertinimo ataskaita. Available at: http:/www.jrd.lt/uploads/ES\%20I/GALUTINE\%20ATASKAITA\%20Klaipeda.pdf.

Jaunimo problemu sprendimo Klaipédos miesto savivaldybèje 2013-2018 m. planas. (2018). Available at: https://www. klaipedos-r.lt/go.php/lit/Del-jaunimo-problemu-sprendimo-klaipedos-rajono-savivaldybeje-20132018-metu-planopriemoniu-plano-20162018-metams-patvirt

Jaunimo situacijos Kauno mieste tyrimas. (2011). Available at: http://vini.lt/wp-content/uploads/2011/03/Kauno-miesto-jaunimo-situacijos-tyrimas.pdf.

Klaipédos miesto savivaldybès 2013-2020 strateginis plètros planas. (2012). Available at: https://www.klaipeda.lt/ data/wfiles/file15722.pdf

Lithuanian Youth Policy: Legislation, Structures, Good Practices. (2013). Available at: http://www.jrd.lt/informacijadirbantiems-su-jaunimu/metodiniai-leidiniai/el-biblioteka/jrd.pdf

Liukinevičienè, L. (2011). Youth Employment Policy Career Guidance of School children in North-western Lithuania. Socialiniai tyrimai / Social Research, No. 4 (25), p. 64-74.

Merkys, G., Brazienė, R., Kondrotaitè, G. (2008). Subjektyvi gyvenimo kokybe kaip socialinis indikatorius: viešojo sektoriaus kontekstas. Viešoji politika ir administravimas, Nr. 23, p. 23-38.

Mixed Methods in Youth Research. (2005). Ed. Helene Helve. Juvenes Print, Tampere. Available at: http://www.nuorisotutkimusseura.fi/images/julkaisuja/mixedmethods.pdf

Nacionaline jaunimo politikos 2011-2019 metu plètros programa. (2010). Available at: https://www.e-tar.lt/portal/lt/ legalAct/TAR.10A2087E3527

Rodrigues, C. (2011). Universities, the Second Academic Revolution and Regional Development: A Tale (Solely) Made of “Techvalleys"? European Planning Studies, Vol. 19, Issue 2, p. 179-194. Available at: https://tandfonline.com/ doi/full/10.1080/09654313.2011.532664.

Specialistų kvalifikacijų žemélapio pirminè analizè. (2015). Mokslo ir studijų stebėsenos ir analizès centras. Available at: http://mosta.lt/images/leidiniai/Specialistu kvalifikaciju zemelapio pirmine analize 2015.pdf.

The Future of the Council of Europe Youth Policy: Agenda 2020. (2008). Available at: https://rm.coe.int/1680702428

Youth Policy in Lithuania (2003). Report by the International Team of Experts 2002. Available at: https://pjp-eu.coe. int/documents/1017981/3084919/COE_youth_policy_Lithuania_En.pdf/117bafdf-e890-43ad-be4f-2d070f910043

Youth Wellbeing Survey. (2014). Available at: https://www.cph.co.nz/wp-content/uploads/youthwellbeingsurvey2013. pdf

Zuoza, R. (2000). Jaunimo pilietinis iniciatyvos skatinimas Lietuvoje. Pedagogika, T. 40, p. 27. 


\title{
KLAIPED OS MIESTO JAUNIMO (16-19 METU) TYRIMAS: GYVENIMO APLINKA IR ATEITIS
}

\author{
GIEDRE் STRAKŠIENE் \\ Klaipėdos universitetas (Lietuva)
}

\section{Santrauka}

Straipsnyje aptariamas tyrimas, igyvendintas vykdant projektą „Strateginės jaunimo politikos ir tarptautinio bendradarbiavimo stiprinimas" (akronimas - CaSyPoT) Nr. STHB.05.01.00-SE-0024/15) pagal 2014-2020 m. INTERREG Pietų Baltijos programą. Pagrindinis projekto tikslas - skatinti jaunimą įsitraukti ị vietos demokratijos ir valdymo procesus, išryškinant jaunimo vaidmenį šiuolaikinès visuomenès vystymosi kontekste. Vykdant projektą, $2017 \mathrm{~m}$. balandžio-gegužès mèn., parengtas ir atliktas jaunimo situacijos tyrimas (anketinė apklausa) Pietų Baltijos regiono šalyse. Surinkti duomenys apdoroti, atliktas analitinis darbas.

Šiame straipsnyje pristatomi Klaipėdos universiteto Socialinių pokyčių centro mokslininkų Klaipėdos savivaldybejje atlikto tyrimo rezultatai. Atliekant longitudini tyrimą pateikti klausimai, susiję su jaunimo gerovès ir saugos patirtimi, mokymosi aplinka, laisvalaikiu, sveikata, gebejjimu ir noru ịsitraukti ị socialines bei politines veiklas, ateities planais.

Tyrimo grupę sudare 404 jaunuoliai nuo 16 iki 19 metų amžiaus iš 8 Klaipėdos rajono mokyklų. Apibendrindami galime teigti, kad tyrimas atskleidè jaunų žmonių nuomones ir įvairias problemas.

Daugelis apklaustų jaunuolių kaip saugiausią vietą ịvardijo namus ar teritoriją netoli gyvenamosios vietos. Nemaža dalis respondentų pripažino, kad susiduria su tokiomis problemomis kaip patyčios, didžioji jų dalis pažymejjo, kad dažniausia tai vyksta mokykloje ir internete. Dauguma mokinių atsakè, kad žino, kur kreiptis pagalbos, esant patyčioms. Be to, tyrimas atskleidè, kad 16-19 metu jaunuoliai labiausiai pasitiki savo tèvais, mažiausiai - politikais ir religinių organizacijų vadovais. Didžioji dalis jaunuolių turi savo siekių, daug laiko praleidžia mokydamiesi, įdomiai leidžia laisvalaikị. Nustatyta, kad nemažai jaunuolių domisi socialiniais klausimais, vietinèmis problemomis, įvykiais pasaulyje. Be to, socialiniai klausimai jiems atrodo aktualesni nei politiniai.

Tapo aišku, kad apie 70 procentų respondentu, baigę mokslus, planuoja išvykti iš Klaipėdos miesto. Studijos užsienyje, gerai apmokamas darbas ir šeima - tai vienos svariausių priežasčių, kodèl jaunuolis apsisprendžia išvykti iš savo savivaldybès. Daugelis paauglių dar neapsisprendè dẻl būsimos profesijos, dalis jų planuoja mokytis toliau, kiti - dirbti, maža dalis -kurti nuosavą verslą.

Atviruosiuose jaunuolių atsakymuose kartais pasitaikydavo grubių ir nepagarbių atsakymų. Rašybos, stiliaus ir gramatikos klaidos buvo gana dažnos. Nepaisant to, galima pastebèti, kad daugeliu atvejų mokiniai atsakinèjo susidomèję ir nuoširdžiai.

JEL KLASIFIKACIJA: H51, H52, H53, H75. 